EDWARD SHARPE-DAVIDSON

\title{
SHOULD THE COURTS ASSESS THE MERITS OF A DISPUTE REFERRED TO ARBITRATION?
}

Submitted for the LLB (Honours) Degree

Faculty of Law

Victoria University of Wellington

2014 


\begin{abstract}
Article 8(1) of Schedule 1 of the Arbitration Act 1996 requires courts to stay proceedings brought on a matter which is the subject of an arbitration agreement except where there is in fact no dispute. The Court of Appeal in Zurich v Cognition interpreted this exception as allowing the courts to assess whether the defendant has an arguable defence to the summary judgment proceedings brought against it. By allowing the court to assess the merits of a dispute referred to arbitration New Zealand is inconsistent with the theoretical and international understandings which require the independence of international arbitration. Court proceedings on a matter referred to arbitration have the potential to rob the parties of the benefits of persisting with arbitration. It is therefore necessary to consider alternatives to art 8(1) which are principally, comparatively and practically sound.
\end{abstract}

Key words: Arbitration Act, article 8(1), added words. 


\section{Table of Contents}

I PURPOSE

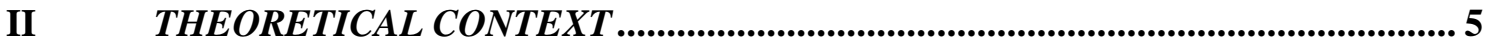

A Limiting Judicial Intervention .................................................................................... 5

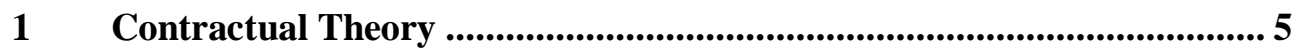

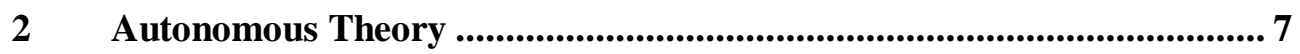

B Extending judicial intervention ..................................................................................... 8

$3 \quad$ Jurisdictional Theory ...................................................................................... 8

C Conclusion ............................................................................................................................. 9

III INTERNATIONAL CONTEXT ................................................................................ 10

A The New York Convention ............................................................................................. 10

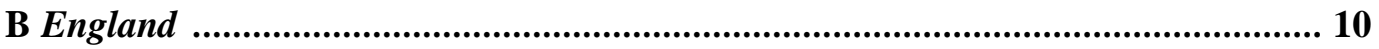

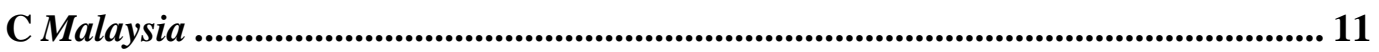

D Canada

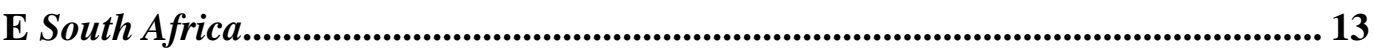

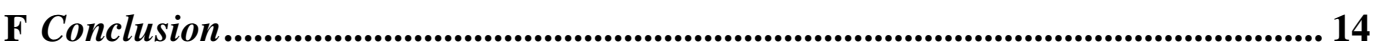

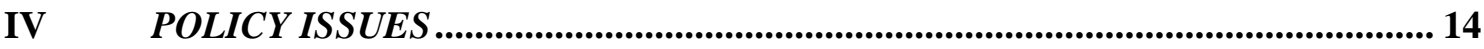

A Efficiency ............................................................................................................................... 14

B Appropriateness of the Forum ............................................................................................... 16

C Conclusion ................................................................................................................................ 17

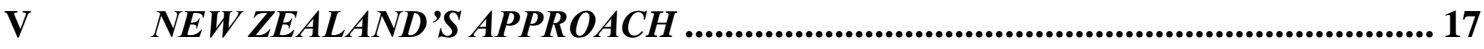

A Before the 1996 Act............................................................................................................... 17

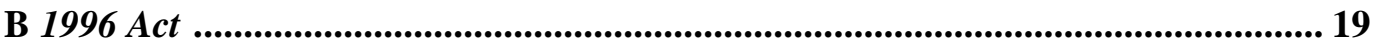

C The New Zealand Law Commission Reports............................................................ 20

D Reasoning in Zurich v Cognition......................................................................................... 22

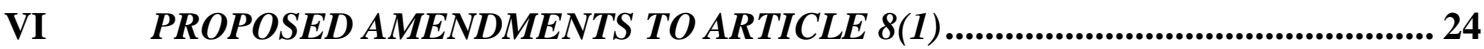

A Deleting the Added Words............................................................................................. 24

B The Subjective Approach ................................................................................................ 25

C The Heightened Objective Approach ............................................................................... 25

D Optional Application of the Added Words .................................................................... 26

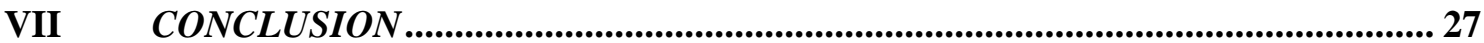

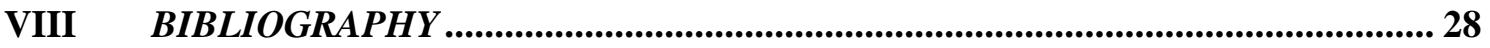




\section{PURPOSE}

Parties who submit their disputes to be determined by an arbitrator generally honour their agreement. Problems arise if one party can invoke the arbitration agreement simply in order to hear a frivolous dispute. In such circumstances should the courts provide an escape for a party who would otherwise be forced to proceed with a full-scale arbitration?

In Cognition v Zurich Cognition claimed that Zurich had no arguable defence for refusing to indemnify Cognition under their insurance policy. ${ }^{1}$ Despite an arbitration agreement, Cognition sought summary judgment in the High Court. ${ }^{2}$

The claimant relied on Article 8(1) of the First Schedule of Arbitration Act 1996. Article 8(1) makes certain exceptions to the rule that the courts will generally enforce arbitration agreements:

\section{Arbitration agreement and substantive claim before court}

(1) A court before which proceedings are brought in a matter which is the subject of an arbitration agreement shall...stay those proceedings and refer the parties to arbitration unless it finds that the agreement is null and void, inoperative, or incapable of being performed, or that there is not in fact any dispute between the parties with regard to the matters agreed to be referred. [emphasis added]

Cognition's argued its claim was brought within the exception to the mandatory stay of proceedings where there is not in fact any dispute between the parties because Zurich allegedly had no arguable defence for its refusal to indemnify Cognition. ${ }^{3}$ The Court of Appeal in Zurich v Cognition agreed with the High Court that the appropriate test for determining whether to stay court proceedings under art 8(1) depended upon whether a party had an arguable defence. ${ }^{4}$ Zurich argued unsuccessfully that the Court did not have jurisdiction to determine the merits of a matter referred to arbitration. ${ }^{5}$

Three considerations are relevant to determining whether New Zealand courts should have jurisdiction to assess the merits of a dispute referred to arbitration. Firstly an understanding of why courts generally recognise the validity of agreements to settle disputes by arbitration helps explain why when the courts will no longer enforce such agreements.

\footnotetext{
${ }^{1}$ Cognition Education Ltd v Zurich Australian Ltd t/a Zurich New Zealand [2012] NZHC 3527 at [3].

2 Ibid at [2].

${ }^{3}$ Ibid at [10].

${ }^{4}$ Ibid at [52] and Zurich Australian Insurance Ltd t/a Zurich New Zealand v Cognition Education Ltd [2013] NZCA 180 at [77].

${ }^{5}$ See Zurich v Cognition, above n 4, at [76].
} 
Secondly the level of judicial intervention acceptable overseas is relevant to whether New Zealand's decision to extend such intervention is justified. International consistency is necessary if New Zealand is to meet its international obligations and to facilitate dispute resolution through international arbitration agreements.

Thirdly matters of policy are important in determining the readiness of courts to interfere. The promise of an escape from an arbitration agreement may be a false dawn if it substantially robs the parties of the practical advantages of persisting with their arbitration.

This research will suggest that greater independence of arbitration from the courts is theoretically, comparatively and practically appropriate; and that this is true at least in regard to international arbitration agreements. Accordingly several alternatives to art 8(1) will be suggested.

\section{THEORETICAL CONTEXT}

Zurich held that the courts may assess the merits of a dispute referred to arbitration. ${ }^{6}$ Is such intervention consistent with the reasons for why parties are allowed to settle their disputes by arbitration? Judicial intervention must be limited if arbitration is a contract or as an autonomous institution. Extending judicial intervention can only be justified if the state's power to control the activities in its territory is clearly established. The theory which most comprehensively describes the present status of arbitration must inform the question of whether the courts may assess the merits of a dispute referred to arbitration.

\section{A Limiting Judicial Intervention}

\section{$1 \quad$ Contractual Theory}

\section{(a) Definition}

The contractual theory argues that the legal basis of arbitration is contractual and that therefore arbitration must be conducted according to the parties' wishes expressed within their agreement. ${ }^{7}$ The arbitrator is conceived of as the agent of the contracting parties with authority deriving from the arbitration agreement. ${ }^{8} \mathrm{An}$ agreement to refer disputes to an arbitrator for a final determination is seen as a legitimate extension of the freedom of parties to contract. ${ }^{9}$

\footnotetext{
${ }^{6}$ See Zurich v Cognition, above n 4, at [77].

${ }^{7}$ Reily v. Russel (1864) 34 Mo 524 at 528.

${ }^{8}$ Adam Samuel Jurisdictional Problems in International Commercial Arbitration - A Study of Belgian,

Dutch, English, French, Swedish, Swiss, US and West German Law (Schulthess, Zurich, 1989) at 34.

${ }^{9}$ Kenneth S. Carlston "Theory of the Arbitration Process" (1952) 17 LCP 631 at 635.
} 
If the parties' wishes are paramount then the courts necessarily have limited control over the procedure and outcome of arbitration. ${ }^{10}$ If an arbitration agreement is a contract, it is a social imperative that the courts hold a party to their promise to settle their disputes through arbitration. ${ }^{11}$

\section{(b) Limitations}

There are difficulties with characterising arbitration as a contract. Kenneth S. Carlston describes a contract as an agreement that the contracting parties reach after a process of negotiation. ${ }^{12}$ An arbitration agreement however assumes that the parties will not or cannot agree on a matter. ${ }^{13}$ It assumes that negotiation is or will no longer be an adequate basis for regulating the conduct of the contracting parties. ${ }^{14}$ If contracts are enforced by the state only because they represent the crystallisation of the negotiation process; an alternative basis for the enforcement of arbitration agreements may need to be found. Carlston describes arbitration as a procedure or a method rather than an agreement. ${ }^{15}$ Arbitration may have a legal significance outside contract law.

The consensual basis of the contractual theory does not account for situations where the state makes arbitration of certain disputes compulsory or arbitration of specific disputes forbidden. ${ }^{16}$ In the interests of public policy some countries such as the United States have encouraged the use of arbitration to resolve labour disputes whereas a number of European jurisdictions have refused to enforce such agreements. ${ }^{17}$ This reality gives emphasises to the supervisory powers of the national courts over arbitration as explained by the jurisdictional theory.

\section{(c) Judicial intervention}

The contractual theory argues that parties to an arbitration agreement voluntarily forgo their right to resolve their disputes in court and that the state should respect their choice to do this by staying court proceedings. ${ }^{18}$ Exceptions would be where the validity of the agreement can be challenged on procedural grounds generally available in contract law. ${ }^{19}$ This may be where the agreement is invalid

${ }^{10}$ Hong-lin $\mathrm{Yu}$ "A Theoretical Overview of the Foundations of International Commercial Arbitration" (2008) 1CAA 255 at 265-266.

${ }^{11}$ See Carlston, above n 9, at 632.

12 Ibid.

${ }^{13}$ Ibid.

${ }^{14}$ Ibid.

${ }^{15}$ Ibid.

${ }^{16}$ See Yu, above n 10, at 267.

${ }^{17}$ Gary B. Born International Arbitration: Cases and Materials (Wolters Kluwer, New York, 2011) at 394.

${ }^{18}$ See Yu, above n 10, at 266.

${ }^{19}$ See Born, above n 17, at 340. 
and cannot be performed. ${ }^{20}$ Assessing the merits of a dispute is a matter for the arbitrator to decide because such disputes are within their sole jurisdiction as has been expressed by the party wishes. ${ }^{21}$

\section{$2 \quad$ Autonomous Theory}

(a) Definition

The autonomous theory would conceive of arbitration as part of a legal framework of its own. This theory has been articulated by Jacqueline Rubellin-Devicihi who stated that: ${ }^{22}$

Only an original system, free from both the contractual and jurisdictional notions, would permit the necessary speed and guarantees which the parties legally claim to be brought together.

It follows that parties should have full autonomy to shape their arbitration and that the laws in the place of arbitration have no supervisory powers. ${ }^{23}$ Rather the parties should be free to choose what law applies to their arbitration. ${ }^{24}$ The choice of law is not limited to national laws. It can include a set of rules governed by custom or broad ideas of fairness and justice. ${ }^{25}$ Arbitration agreements and awards are to be enforced generally to respect the autonomy of parties to resolve their disputes in such a way. ${ }^{26}$

\section{(b) Limitations}

The autonomous theory has been criticised for discounting the importance of the place of arbitration. ${ }^{27}$ Francis A. Mann argues that there is no legal principle which allows individuals to act independently of the laws of a nation. ${ }^{28}$ It may be that the autonomy theory is subversive in the sense that it does not reflect legal realities.

Mann also argues that if arbitration is to succeed in providing a final and binding determination the law of the land is the only set of rules with sufficient authority to enforce arbitral awards. ${ }^{29}$ Customs or general principles of fairness may lack the authority to be binding on the parties. Resort must

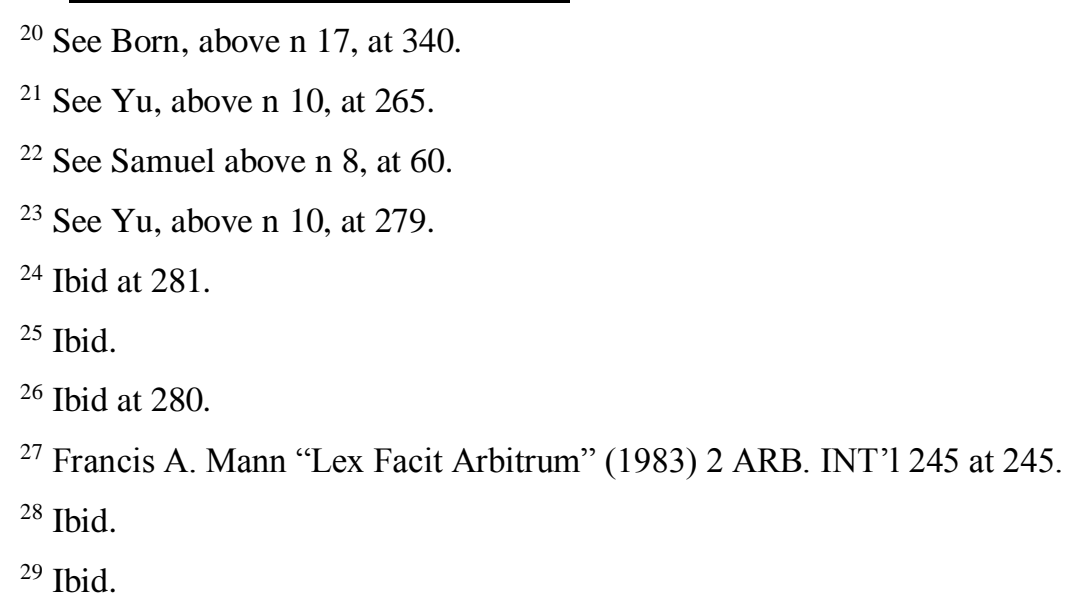


necessarily be had to the national courts. It may be that arbitration currently lacks the capacity to operate fully independently from the courts.

\section{(c) Judicial intervention}

The autonomous theory does not recognise a national court's ability to legislate to supervise arbitration seated in their territory. ${ }^{30}$ This would impinge on the autonomy of the parties to conduct their arbitration.

\section{B Extending Judicial Intervention}

\section{$1 \quad$ Jurisdictional Theory}

\section{(a) Definition}

The premise of the jurisdictional theory is that a state may regulate the activities carried out within its territory. ${ }^{31}$ The validity of an arbitration agreement arises from the fact that it is in the public interest to encourage the use of arbitration as a means of dispute resolution. ${ }^{32}$ In meeting the public interest the state must supervise how arbitrations are conducted and determine what disputes are arbitrable. $^{33}$

The jurisdictional theory contends that the power to settle disputes is generally the prerogative of the state. ${ }^{34}$ However if an arbitration is in the public interest the state will delegate this power to arbitrators. ${ }^{35}$ As delegates of the state, arbitrators must abide by the laws enforced in the place of arbitration. ${ }^{36}$

\section{(b) Limitations}

Supervisory powers of the seat of arbitration may restrict arbitration from becoming an effective means of resolving disputes internationally. Ole Lando argues that this is because of difficulties caused by the unfamiliarity of national laws to a foreign party. ${ }^{37}$ As an example he points to how the common law rules on consideration and privity of contract are foreign to those from countries with

\footnotetext{
${ }^{30}$ See Yu, above n 10, at 282.

${ }^{31}$ Ibid at 257.

${ }^{32}$ See Carlston, above n 9, at 633-634.

${ }^{33}$ See Yu, above n 10, at 259.

${ }^{34}$ Ibid at 261.

${ }^{35}$ Ibid.

${ }^{36}$ Ibid at 262.

37 Ole Lando "The Lex Mercatoria in International Commercial Arbitration” (1985) 34ICLQ 747 at 748.
} 
different legal systems. ${ }^{38}$ Thus the party from the seat of arbitration may have an advantage over the foreign party in an international arbitration when it comes to enforcing agreements. It is suggested that the application of a law that transcends national laws or the ability of the parties to choose what law applies to their arbitration regardless of the seat would avoid this difficulty. ${ }^{39}$ However the autonomous theory is a significant inroad into the sovereign of the state. The need for such action is mitigated by international agreements such as UNCITRAL Model Law on International Commercial Arbitration which have promoted uniformity in the conducting of international arbitrations. ${ }^{40}$

\section{(c) Judicial intervention}

If the jurisdictional theory allows a state to regulate the arbitrations that take place in its territory this would mean that a court should have a wide discretion as to whether to stay or allow proceedings on a matter referred to arbitration especially where it is the seat of arbitration. ${ }^{41}$

\section{Conclusion}

There is a compelling theoretical basis for allowing courts to assess the merits of disputes referred to arbitration. This is manifested by the extensive control states have over arbitration. It is difficult to point to the freedom of contract as a justification for reducing judicial intervention. Arbitration is not the same as other contracts. It represents the failure of the negotiation process and parties are not free to arbitrate disputes which the state deems non-arbitrable. Arbitration's reliance on national laws for the enforcement of arbitral awards indicates its current dependence on the courts.

However extending judicial intervention is incompatible with international arbitration. The autonomous theory demonstrates that international parties need a flexible form of dispute resolution if they are to reconcile the differences inherent in their nationalities.

To meet the needs of international parties a distinction may be made between domestic and international arbitration. Courts are justified in assessing the merits of disputes referred to a domestic arbitration. While the merits of disputes referred to international arbitration are to be determined under the sole jurisdiction of the arbitrator.

\footnotetext{
${ }^{38}$ See Lando, above n 37 , at 748.

${ }^{39}$ See Yu, above n 10, at 257.

40 UNCITRAL Model Law on International Commercial Arbitration (United Nations Publications, Vienna, 2008) at art 2A.

${ }^{41}$ See Yu, above n 10, at 259-260.
} 


\section{INTERNATIONAL CONTEXT}

Arbitration agreements with New Zealand parties will seem less secure to international parties if it is unusual to allow courts to assess the merits of a dispute referred to arbitration. The defeating of arbitration agreements by recourse to the courts may be a tactic which is responded by with jurisdictional challenges. A universal consensus on the role of the courts in the arbitral process is therefore desirable.

The New York Convention represents a multi-national effort to decide how international arbitration agreements are to be enforced. ${ }^{42}$ New Zealand's obligations under this treaty will be considered first. ${ }^{43}$

Malaysia has followed England in amending their legislation to prevent the courts from inquiring into whether there is in fact a dispute to refer to arbitration. The explanation for this movement may illuminate why New Zealand has chosen to do the opposite and to keep these words.

In Zurich the Court states that claims that New Zealand is inconsistent with overseas jurisdictions are exaggerated and that a wide discretion over enforcing arbitration agreements is similarly granted to the courts in South Africa and Canada. ${ }^{44}$ The validity of this statement will be assessed by considering the academic opinion, law reform materials and case law in these jurisdictions.

\section{A The New York Convention}

The New York Convention provides in art II(3) that:

The court of a Contracting State...shall...refer the parties to arbitration, unless it finds that the said agreement is null and void, inoperative or incapable of being performed.

The commonly accepted interpretation of art II(3) is that the grounds of invalidity refer to "generally-applicable, internationally-neutral contract law defences." ${ }^{45}$ This interpretation is consistent with the argument that arbitration agreements are no different from other contracts. It limits contracting States from imposing onerous or unusual procedural requirements before they agree to

\footnotetext{
${ }^{42}$ Convention on the Recognition and Enforcement of Foreign Arbitral Awards, (signed 10 June 1958, entered into force 7 June 1959), 330 U.N.T.S. 38, art II.

${ }^{43}$ New Zealand ratified on 6 January 1983 and the treaty would enter into force 6 April 1983. See UNCITRAL "Status - Convention on the Recognition and Enforcement of Foreign Arbitral Awards (New York, 1958)" UNCITRAL <http://www.uncitral.org/uncitral/en/uncitral_texts/arbitration/NYConvention_status.html>

${ }^{44}$ See Zurich $v$ Cognition, above n 5, at [73].

${ }^{45}$ Gary B. Born International Commercial Arbitration ( ${ }^{\text {rd }}$ ed, Klumer Law International, Alphen Aan Den Rijn, 2009) at 710.
} 
recognise the validity of an international arbitration agreement. ${ }^{46}$ The Convention's goal of achieving uniformity in international arbitrations justifies such an approach. ${ }^{47}$

The influence of the New York Convention in this regard and the similar provision adopted by the UNCITRAL in its Model Law on International Commercial Arbitration is also illustrated by the reform of arbitration legislation in England and Malaysia. ${ }^{48}$

\section{B England}

Section 1 of the English Arbitration Act 1975 adopted the language of art II(3) of the New York Convention but imposed an additional ground under which courts could assess the validity of international arbitration agreements, namely where there was "not in fact any dispute between the parties with regard to the matter agreed to be referred [to arbitration]."

In 1996 these added words were dropped on recommendation of the Departmental Advisory Committee on Arbitration Law: ${ }^{49}$

These words do not appear in the New York Convention and in our view are confusing and unnecessary, for the reasons given in Hayter $v$ Nelson.

One of the objections to the added words made in Saville J's judgment in Hayter $v$ Nelson was based on the contractual argument that parties may choose how their dispute is to be resolved. The judge held that to allow a court to assess the merits of a dispute referred to arbitration would be to supplant the parties' agreement to resolve their dispute through arbitration. ${ }^{50}$ The Committee explicitly identified inconsistency with the New York Convention as a reason for dropping the added words. This confirms that the effect of the added words was to limit the jurisdiction of the courts. In amending of arbitration legislation in England in 1996 thus recognises the contractual theory of arbitration and the desirability of international consistency between international arbitral regimes.

\section{Malaysia}

Similarly the Malaysian Arbitration Act 1952, which was based on the English Arbitration Act 1950, was amended in 2005 to prevent courts assessing the merits of a dispute subject to an

\footnotetext{
${ }^{46}$ See Born, above $\mathrm{n}$ at 45 , at 711.

${ }^{47}$ See UNCITRAL Model Law above n 40, at art 2A.

${ }^{48}$ Ibid at art 8(1).

${ }^{49}$ Departmental Advisory Committee on Arbitration Law Report on Arbitration Bill (February 1996) at 55.

${ }^{50}$ Hayter v Nelson \& Home Insurance Co [1990] 2 Lloyd's Rep 265 (QB) at 268-269.
} 
international arbitration agreement. ${ }^{51}$ It was hoped that this amendment would discourage the practice of claimants seeking summary judgment over referring disputes to arbitration. ${ }^{52}$ The Malaysian High Court has confirmed that this is the effect of the amendment, holding that: ${ }^{53}$

It is now no longer possible to argue that in respect of the controversy between the parties there is no "dispute" with regard to the matter to be referred to arbitration.

\section{Canada}

Canadian arbitration legislation initially reflected the view that courts should have a wide discretion over enforcing arbitration agreements. The Alberta Institute of Law Research and Reform 1988 report on Arbitration Law recommended that international arbitration agreements should generally be considered valid but made an exception in s 7(2)(e) of the Alberta Arbitration Act, RSA 2000, C A-43 to refuse a stay of proceeding when the matter in dispute "is a proper one for default or summary judgment. ${ }^{" 54}$ Section 7(2)(e) necessarily gave the courts the ability to assess the merits of a dispute in accordance with default or summary judgment procedure.

Canadian courts have sought to limit the discretion of the courts to refuse a stay under s 7(2)(e). In Balancing Pool v TransAlta Utilities Corporation CJ Wittmann concluded that the provision required it to be proved that a summary judgment motion would be successful. ${ }^{55}$ In Smith Estate v National Money Mart Co Perell J demanded a less stringent standard holding that the motion had a "high prospect of success." ${ }^{56}$ The reasoning of these Canadian Judges reflects Malaysian concerns that arbitration legislation gave the courts to much discretion over whether to stay court proceedings was inappropriately being used as a device to avoid the agreement to arbitrate. ${ }^{57}$

In 2013 the Alberta Law Reform Institute recommended Alberta should repeal s 7(2)(e). ${ }^{58}$ The Institute accepted that since the parties have agreed to arbitration, the decision whether the dispute

51 Arbitration Act (Malaysia) 2005, s10 and Thayananthan Baskaran "Recent Amendments to the Malaysian Arbitration Act" (2012) 28 LCIA 533 at 533.

52 See Baskaran, above n 51, at 535.

${ }^{53}$ KNM Process Systems Sdn Bhd v Mission Biofuels Sdn Bhd [2012] MLJU 1218 at [17].

${ }^{54}$ The Alberta Institute of Law Research and Reform "Proposals for a New Alberta Arbitration Act" (October 1988) at 75-76.

55 Balancing Poolv TransAlta Utilities Corporation, 2008 ABQB 631 at 48.

${ }^{56}$ Smith Estate v. National Money Mart Co., [2008] O.J. No. 2248 at 143.

${ }^{57}$ Ibid at 143.

${ }^{58}$ Alberta Law Reform Institute Arbitration Act: Stay and Appeal Issues 2013 at [84]. 
should be heard in court is within the jurisdiction of the arbitral tribunal. ${ }^{59}$ It is clear that the general trend in Canada since 1988 has been towards the independence of arbitration.

\section{E South Africa}

Under South Africa arbitration legislation the courts maintain a wide discretion over whether to stay a dispute subject to either a domestic or an international arbitration agreement. Under s 6(2) of the Arbitration Act 1965 a court may stay court proceedings if there is:

no sufficient reason why the dispute should not be referred to arbitration in accordance with the [arbitration] agreement.

English and Singaporean arbitration legislation also uses the language of "sufficient reason" to confer discretion on the courts to decide whether to stay proceedings brought in regard to a matter referred to arbitration. ${ }^{60}$ However the discretion is limited to domestic arbitrations. ${ }^{61}$ South Africa's arbitration legislation goes further to realise the jurisdictional theory by extending this supervisory discretion to both international and domestic arbitrations. ${ }^{62}$

According to Desmond Williams the discretion conferred by the words "sufficient reason" has been interpreted as putting on those who seek to avoid an arbitration agreement an onus that is not easily discharged. ${ }^{63}$ One of the factors that the courts will take into account is the maxim pacta sunt servanda. ${ }^{64}$ The South African courts put weight on the contractual idea that parties must be held to their agreement to arbitrate.

On the other hand the discretion conferred on South African judges has been described as "much wider" than is the case in other jurisdictions. ${ }^{65}$ David Butler asserts that there is a "clear need to restrict the Court's powers of interference" into international arbitration agreements. ${ }^{66}$

This view is shared by the South African Law Commission which has proposed an International Arbitration Act based on the UNICTRAL Model Law so as to limit court discretion in relation to

\footnotetext{
${ }^{59}$ See Alberta Law Reform Institute, above n 58, at [82].

${ }^{60}$ Arbitration Act (United Kingdom) 1996, s86(2) and Arbitration Act (Singapore) 2001, s 6(2)(a).

${ }^{61}$ Arbitration Act (United Kingdom) 1996, s 9(4) and International Arbitration Act (Singapore) 1994, s 6(2).

62 Desmond Williams "South Africa" in J. William Rowley QC (ed) Arbitration World (3"rd ed, The European Lawyer Reference, London) at 504.

${ }^{63}$ Ibid at 506.

64 Ibid.

${ }^{65}$ David Butler "South Africa arbitration legislation - the need for reform" (1994) 17 CILSA 118 at 129.

${ }^{66}$ Ibid.
} 
international arbitration agreements. ${ }^{67}$ The Commission hoped that this would bring South African arbitration legislation in line with countries such as England and Singapore and that international consistency in this regard would facilitate international business transactions in South Africa. ${ }^{68}$

\section{F Conclusion}

New Zealand is unusual in its decision to allow courts to assess the merits of matters subject to international arbitration agreements. There are clear movements towards the autonomy of international arbitration even within countries which have traditionally allowed the courts a wide discretion. For New Zealand, its inconsistency with close neighbours Singapore and Malaysia has the potential to disrupt alternative dispute resolution in the Asia-Pacific region. Arbitration agreements with New Zealand parties may come to be perceived as insecure.

\section{POLICY ISSUES}

When parties seek to avoid their arbitration agreement it is because of what they see as the perceived benefits of the summary judgment procedure. Is this a practice that New Zealand should encourage? This section will examine whether it is in the best interests of parties to an arbitration agreement to seek the courts assistance in determining the merits of their disputes.

\section{A Efficiency}

Arbitration may be a more efficient means of resolving disputes than the summary judgment procedure. Parties are free to agree on the procedure to be followed by the arbitral tribunal. This means that parties may, in the interests of expediency, agree to not hold a full evidential hearing. ${ }^{69}$ There are limits to this freedom under art 18 of sch 1 which requires that "the parties shall be treated with equality and each party shall be given a full opportunity of presenting that party's case." The phrase "full opportunity" is generally read as only meaning "reasonable opportunity." 70 The freedom of parties over their arbitration procedure is nevertheless significant.

\footnotetext{
${ }^{67}$ See Williams above $\mathrm{n} 62$, at 503.

${ }^{68}$ South African Law Commission Issue Paper (Project 94) Arbitration: An International Arbitration Act for South Africa (1998) at 20-21.

${ }^{69}$ David A R Williams and Amokura Kawharu Williams and Kawharu on Arbitration (LexisNexis, Wellington, 2011) at [4.13.5] and Arbitration Act (New Zealand) 1996, s 19(1).

${ }^{70}$ See Williams and Kawharu, above n 69, at [11.2.2].
} 
It is arguable whether arbitrations are in practice conducted with optimal expediency. Parties do not often take the opportunity to streamline the procedure that will govern their arbitration. ${ }^{71}$ In such cases the arbitral tribunal may decide on the appropriate procedure. ${ }^{72}$

Summary judgment is itself designed to be an expedient process. The claimant need only prove that the defendant has no arguable defence. ${ }^{73}$ Summary judgment will generally not be available if there are material facts in dispute. ${ }^{74}$ Time is therefore not wasted on cross-examination and discovery. The need to determine complex legal issues in some cases may mean that summary judgment be a slower process than it may seem at first. ${ }^{75}$

Parties to an arbitration agreement have the ability to choose an arbitrator to resolve their dispute. They do not have to deal with the potential backlog in the court system. ${ }^{76}$ This has not necessarily meant that finding an arbitrator is without delay. Ministry of Justice research has found that many lawyers considered appointing an appropriate arbitrator actually entails considerable delay. ${ }^{77}$

Because arbitration has the potential to be a speedy form of dispute resolution one may presume that submission to arbitration would be less costly than to seek summary judgment. This argument may not necessarily hold in the cases of large-scale, complex arbitrations. ${ }^{78}$ But the fear of ever increasing costs is mitigated by New Zealand tribunals providing the option of fixed fee arbitration or an expedited procedure in certain cases. ${ }^{79}$ Nevertheless, from the perception of Alternative Dispute Resolution practitioners, arbitration is currently seen as having a "low-medium" potential for reducing financial costs. ${ }^{80}$ In the absence of comprehensive empirical evidence it may be difficult to make a general statement on the costs of arbitration vis-à-vis summary judgment.

71 Daniel Kalderimis and Andrew Skelton "Summary Judgment and Arbitration: The contest between pragmatism and principle" 17 NZACL 263 at 285.

${ }^{72}$ Arbitration Act (New Zealand) 1996, s 19(2).

${ }^{73}$ High Court Rules, r 12.2 and Jowada Holdings Ltd v Cullen Investments Ltd CA248/01, 5 June 2003 at [28]-[30].

${ }^{74}$ See Jowada Holdings Ltd v Cullen Investments Ltd, above n 73, at [28]-[29].

${ }^{75}$ Pemberton v Chappell [1987] 1 NZLR 1 (CA) at 4 and Kalderimis and Skelton, above $\mathrm{n}$ 71, at 280.

${ }^{76}$ See Williams and Kawharu, above n 69, at [1.1.5].

${ }^{77}$ K. Saville-Smith and R. Fraser Alternative Dispute Resolution: General Civil Cases (Ministry of Justice, June 2004) at [3.3].

${ }^{78}$ See Williams and Kawharu, above n 69, at [1.1.5].

${ }^{79}$ See the websites for the New Zealand Dispute Resolution Centre (www.nzdrc.co.nz) and the Building Disputes Tribunal (www.buildingdisputestribunal.co.nz).

${ }^{80}$ See Saville-Smith and Fraser, above n 77, at Infobox 4.1. 


\section{B Appropriateness of the Forum}

The autonomy international parties have as to procedure means that parties may reconcile their different understandings as to legal systems and philosophy. ${ }^{81}$ The ability to choose an arbitrator means that the parties may dismiss the concern that the dispute will be determined by someone with a nationality bias. ${ }^{82}$ The arbitrator's loyalty is said to rest primarily with the parties. ${ }^{83}$

One way the nationality bias of the courts manifests is in the fact that it may be difficult for domestic parties to bring legal action against international parties. An international party may object to the jurisdiction of New Zealand courts under r 5.49(7) of the High Court Rules. The courts have discretion whether to assume jurisdiction under $\mathrm{r}$ 6.29. Whether New Zealand is an appropriate forum is one of the considerations taken into account under $r$ 6.28(5). Under r 6.29(3) a domestic party may also challenge the jurisdiction of New Zealand courts. In determining whether New Zealand is an appropriate forum the strength of the defendant's connection with the country is relevant. ${ }^{84}$ International parties may point to their geographical location as indicating their connection with New Zealand is weak. ${ }^{85}$ This argument is not necessarily available to a domestic party wishing to bring court proceedings against an international party. However, if an international party has agreed to New Zealand as the seat of arbitration, it will be difficult to maintain that their connection with New Zealand is weak. ${ }^{86}$

Parties to arbitration have consented to the jurisdiction of the arbitral tribunal. ${ }^{87}$ Therefore parties do not face the difficulty of trying to impose the jurisdiction of a domestic court on an international party. As a party to the New York Convention New Zealand will generally recognise arbitral awards which have been made in the more than 130 countries who have also agreed to the Convention. ${ }^{88}$ Arbitration seems to be more an appropriate than the national courts for the resolution of disputes between international parties.

\footnotetext{
81 Julian DM Lew and others, Comparative International Commercial Arbitration (Kluwer Law International, The Hague, 2003) at [1.3].

${ }^{82}$ Ibid at [1.13].

${ }^{83} \mathrm{Ibid}$ at [1.23].

${ }^{84}$ Wing Hung Printing Co v Saito Offshore Pty Ltd [2011] 1 NZLR 754 (CA) at [30].

${ }^{85}$ Daniel Kalderimis and Nikolas Bruce-Smith "To stay or not to stay” (2013) NZLJ 232 at 234.

${ }^{86}$ Ibid at 234.

${ }^{87}$ See Samuels, above n 8, at 34.

${ }^{88}$ New Zealand ratified on 6 January 1983 and the treaty would enter into force 6 April 1983. See UNCITRAL

"Status - Convention on the Recognition and Enforcement of Foreign Arbitral Awards (New York, 1958)" UNCITRAL <http://www.uncitral.org/uncitral/en/uncitral_texts/arbitration/NYConvention_status.html>
} 
Commercial parties may wish to resolve their disputes without being scrutinised by third parties or the media. The New Zealand Arbitration Act addresses such concerns by providing a statutory basis for arbitration to be conducted in private and for presuming that parties have agreed to not disclose confidential information. ${ }^{89}$ The presumption of confidentiality is reversed by s14F (1) in favour of open hearings when court proceedings are brought under the Act. If one party brings a summary judgment application under the Act they are directly challenging the confidentiality of the dispute.

The other party may respond with an application to stay proceedings. Under $r 7.36$ of the High Court Rules applications for a stay must be heard in private unless a judge directs otherwise. The courts willingness to protect confidentiality has been seen in how the High Court has considered that not only the fact of a stay of proceedings in favour of arbitration but also a pending application for a stay is relevant to its decision to decline media access to the court file. ${ }^{90}$ Nevertheless if the stay application fails summary judgment invites the sort of public scrutiny that a party to arbitration may not have bargained for or would have consented to. Court proceedings under the Act undermines the consensual foundation of arbitration and the added protection afforded by the presumption of confidentiality in arbitral proceedings.

\section{Conclusion}

Arbitration potentially offers parties an effective dispute resolution procedure tailored to their needs. The benefits of arbitration are threatened if a court has jurisdiction to assess the merits of a dispute referred to arbitration. This is especially true for international parties. This conclusion is consistent with the principled and comparative arguments above. There should be greater independence for parties to an international arbitration agreement, but a case can be made for preserving judicial intervention into domestic arbitration agreements.

\section{NEW ZEALAND'S APPROACH FOLLOWING ZURICH v COGNITION}

\section{A Before the 1996 Act}

Before 1996 New Zealand's arbitration legislative scheme consisted of the Arbitration Act 1908 which governed domestic arbitrations and the Arbitration (Foreign Agreements and Awards) Act 1982 which governed international arbitrations. ${ }^{91}$

\footnotetext{
${ }^{89}$ Arbitration Act (New Zealand) 1996, ss 14A and s 14B(1).

${ }^{90}$ Danone Asia Pacific Holdings Pte Ltd v Fonterra Co-Operative Group Ltd [2014] NZHC 393 at [33] and Ngai Tahu Justice Holdings Ltdv Attorney-General [2013] NZHC 801 at [14].

${ }^{91}$ Baltimar Aps Ltd v Nalder \& Biddle Ltd [1994] 3 NZLR 129 (CA) at 135.
} 
Under s 5 of the Arbitration Act 1908 the court had a wide discretion to refer a dispute back to arbitration:

...the Court, if satisfied that there is no sufficient reason why the matter should not be referred in accordance with the submission...may make an order staying the proceedings.

In Royal Oak Mall Ltd v Savory Holdings Ltd it was held that the appropriate test was to determine whether the defendant had an arguable defence to a claim for summary judgment. ${ }^{92}$ This necessarily involved a court considering the merits of a dispute referred to arbitration and thus reflected the theory that courts may supervise the activities that take place under its territory.

International arbitration agreements were originally governed by the Arbitration Clauses (Protocol) and the Arbitration (Foreign Awards) Act $1933 .{ }^{93}$ This Act similarly gave the court a wide discretion under s 3:

....unless [the Court is] satisfied that the agreement or arbitration has become inoperative or cannot proceed, or that there is not in fact any dispute between the parties with regard to the matter agreed to be referred shall make an order staying the proceedings. [emphasis added]

In 1982 the Arbitration (Foreign Agreements and Awards) Act was passed which significantly limited the court's discretion to allow court proceedings on a matter subject to an international arbitration agreement under s 4(1):

...the Court shall, unless the arbitration agreement is null and void, inoperative, or incapable of being performed, make an order staying the proceedings.

Daniel Kalderimis and Andrew Skelton contend that the repeal of s 3 was "to ensure that New Zealand legislation was consistent with art II(3) of the New York Convention" to which New Zealand was a party. ${ }^{94}$ The authors rely on express references in the Bill to the power to stay legal proceedings and the description of the New York Convention's purpose as being to "avoid some of the legal shortcomings revealed by earlier legislation and conventions." 95

The case of Baltimar Aps Ltd v Nalder \& Biddle Ltd supports this view. In Baltimar the Court of Appeal held that the repeal of the 1933 Act meant that the courts could no longer look at the merits of a dispute referred to arbitration. ${ }^{96}$ New Zealand endorsed the contractual view of international

\footnotetext{
92 Royal Oak Mall Ltd v Savory Holdings Ltd CA106/89, 2 November 1989 at 9.

93 Arbitration Clauses (Protocol) and the Arbitration (Foreign Awards) Act 1933, long title.

${ }^{94}$ See Kalderimis and Skelton, above n 71, at 270 and above at section 3.

${ }^{95}$ See Kalderimis and Skelton, above n 71, at 270.

${ }^{96}$ See Baltimar Aps Ltd v Nalder \& Biddle Ltd, above n 91, at 135.
} 
arbitration by limiting the court's discretion to assess the merits of disputes subject to international arbitration agreements.

\section{B 1996 Act}

Before the 1996 Act it was clear that New Zealand recognised that domestic arbitration had a different theoretical basis than that which underpinned international arbitration. The former being justified by the jurisdictional theory, the latter being justified by the contractual theory.

In this context it seems odd that in 1996 New Zealand would pass an Act that reinstated a wide discretion for the court to assess disputes referred to arbitration, regardless of it being subject to an international or domestic arbitration agreement. ${ }^{97} \mathrm{~A}$ wide discretion was enacted through the "added words" in art 8(1) which gave the courts the power to allow court proceedings if:

there is not in fact any dispute between the parties with regard to the matters agreed to be referred [to arbitration].

It seems easier to justify in principle that a national court should have extensive powers to supervise the activities of its citizens. As illustrated above, this has been borne out internationally with Singapore and England giving courts a wide discretion to assess disputes subject to domestic arbitration agreements while limiting court discretion as to international arbitration agreements. ${ }^{98}$ It is harder to justify in principle that courts should assume a wide discretion over international agreements. It may be seen as an illegitimate extension of the jurisdictional theory, conflicting with the jurisdiction countries overseas have over their own citizens. ${ }^{99}$

The added words in art 8(1) are inconsistent with the purposes of the 1996 Act to promote international consistency with arbitral regimes. ${ }^{100}$ South Africa is an example of a country with a uniform standard for international and domestic arbitrations. However its Law Commission has recommended following the UNICTRAL standard which incorporates the art II(3) of the New York Convention and which limits court discretion. ${ }^{101}$ As noted above, internationally, the general movement is towards the greater independence of arbitration, or at least in regard to international

\footnotetext{
97 The added words in art 8(1) are contained in Arbitration Act 1996, Schedule 1. These rules apply to arbitration generally.

${ }^{98}$ See above in section $3 E$.

99 Yu may disagree; see Yu, above n 10, at 259-260.

100 Arbitration Act (New Zealand) 1996, s 5(b).

${ }^{101}$ See Williams above n 62, at 503.
} 
arbitration. ${ }^{102}$ New Zealand is inconsistent with international developments by assimilating international and domestic arbitration under the jurisdictional theory and this raises the issue of whether arbitration agreements with New Zealand parties will be looked down on as being unsecure.

\section{The New Zealand Law Commission Reports}

The Court of Appeal in Zurich considered that the 1991 and 2003 Law Commission reports on arbitration supported the argument that Parliament intended that an arguable defence test needed to be satisfied under art 8(1) before court proceedings would be stayed in favour of arbitration. ${ }^{103}$ This section will show that this claim is based on an uncertain footing which does not taken into account recent international developments.

In 1991 the Law Commission recommended the inclusion of the added words. It relied on a passage from the English Mustill Committee Report 1990 which indicated that the added words were of "great value in disposing of applications for a stay by a defendant who has no arguable defence." 104 The Court of Appeal says that this would mean that the "existing New Zealand legal position and practice since the decision of Royal Oak would continue under the new statute [of 1996]."105

The English text The Law and Practice of Commercial Arbitration in England was first published two years before the 1991 New Zealand Law Commission report and as an author Lord Mustill with Stewart Boyd expressed ambivalence towards how the words had been interpreted by English Judges: ${ }^{106}$

There are strong logical arguments for the view that bona fide if unsubstantial defence ought to be ruled upon by the arbitrator, not the Court. This is so especially where there is a non-domestic arbitration agreement.

The views expressed by Lord Mustill and Boyd in their textbook suggest that the Law Commission's reliance on the Mustill Committee Report can no longer be taken to have meant that the arguable defence test should continue to apply. The Court of Appeal itself refers to the English textbook to assert that the arguable defence test was "quite clearly established" law on how the added

\footnotetext{
102 See above in section $3 \mathrm{~F}$.

${ }^{103}$ See Zurich v Cognition, above n 5, at [68].

104 “A New Arbitration Act for the United Kingdom? The Response of the Departmental Advisory Committee to the UNCITRAL Model Law" (1990) 6 Arbitration International 3 at 53 and Law Commission Arbitration (NZLC R20, 1991) at [308].

105 See Zurich v Cognition, above n 5, at [69].

${ }^{106}$ Lord Michael Mustill \& Stewart Boyd, The Law and Practice of Commercial Arbitration in England (2nd ed, Butterworths, London, 1989) at 123.
} 
words were to be interpreted and as a basis for the New Zealand decision in Royal Oak. ${ }^{107}$ But it seems that the Court has failed to read this 'endorsement' in the context of Lord Mustill's reservations about the arguable defence test. It is suggested that the Mustill Committee Report be read in this context of these misgivings.

Further there is the fact that the relevant section in the Arbitration Act 1908 under which Royal Oak was decided is worded differently from the 1996 Act and only applied to domestic arbitration agreements. ${ }^{108}$ The Arbitration Act 1996 has a different subject matter; it applies to both international and domestic arbitration. ${ }^{109}$ Mustill and Boyd were especially concerned about allowing Courts a wide discretion over international arbitration agreements as has been stated immediately above.

The subsequent recommendation in 1996 by the Departmental Advisory Committee on Arbitration Law to drop the added words has already been discussed. ${ }^{110}$ It further illustrates that the reliance the Law Commission placed on the English position in adopting the added words must be reassessed. Law reform experts in the United Kingdom no longer support extending judicial intervention into international arbitration agreements.

The Law Commission in 1991 also relied on the recommendation in the Alberta ILRR report that: ${ }^{111}$

A Court be empowered to refuse to stay an action if "the case is a proper one for a default or summary judgment."

The Court of Appeal may be mistaken to rely on this aspect of the Law Commission Report to support the adoption of an arguable defence test. As discussed earlier the Canadian courts have interpreted this provision narrowly, requiring that a summary judgment claim have a high chance of success. ${ }^{112}$ This is inconsistence with a threshold for summary judgment is merely an arguable claim. In recommending the Canadian approach it may be that the Law Commission was actually suggesting that the effect of the added words was to grant a court a level of discretion, but that the courts should be slow to exercise such discretion. This interpretation would be to take steps to align the added words with the Act's stated purpose of reducing judicial intervention. ${ }^{113}$

\footnotetext{
${ }^{107}$ See Zurich $v$ Cognition, above n 5, at [34].

${ }^{108}$ See Zurich $v$ Cognition, above n 5, at [36] and above in section 5A.

${ }^{109}$ See above in section 5B.

${ }^{110}$ See above in section 3B.

111 See Zurich v Cognition, above n 5, at [43].

${ }^{112}$ See above in section 3D.

113 Arbitration Act (New Zealand) 1996, sch 1 art 5.
} 
In 2003 the Law Commission reviewed the Arbitration Act 1996. While the Commission's report recognised criticism of the arguable defence approach it was not prepared to recommend law reform. ${ }^{114}$ Parliament's acceptance of this report is strong evidence that Parliament intends art 8(1) to be interpreted as importing an arguable defence test. Law reform may therefore be necessary if this approach is to change.

\section{Reasoning in Zurich v Cognition}

The Court of Appeal rejected the argument that it should stay proceedings under art 8(1) for a bona fide, albeit unarguable defence. ${ }^{115}$ The Court preferred the summary judgment test which asks whether the defendant has an arguable defence. ${ }^{116}$ The argument for a bona fide test was rejected as being an argument for what the "New Zealand Parliament should have enacted, as opposed to what it did enact." 117

By adopting the arguable defence test the New Zealand courts have given further recognition to the jurisdictional theory as a basis for international and domestic arbitration. This threshold makes it easier for parties to circumvent arbitration agreements than if the court was to adopt a higher objective threshold or a bona fide test. ${ }^{118}$

The Court of Appeal states that claims "that New Zealand is out of step with the rest of the world on this issue...appear to be overstated." ${ }^{119}$ Canadian and South African legislation are referred to in order to prove this point. ${ }^{120}$ However the widely accepted approach to stay applications is considered to be that formulated at the New York Convention and adopted in the UNCITRAL's Model Law on Commercial Arbitration. ${ }^{121}$ The New York Convention does not include the added words. ${ }^{122}$ Further Canada and South Africa seem to require higher levels of proof before they will exercise their discretion and allow court proceedings. As discussed above a number of factors guide the South African courts, one of them being pacta servana sunt, the principle that agreements are to be kept. ${ }^{123}$ In Canada the requirement for the plaintiff's claim to have a "high prospect of success" seems to

\footnotetext{
${ }^{114}$ Law Commission Improving the Arbitration Act 1996 (NZLC R83, 2003) at [245].

${ }^{115}$ See Zurich v Cognition, above n 5, at [68]-[69].

${ }^{116}$ Ibid at [78].

${ }^{117}$ See Zurich v Cognition, above n 5, at [8].

${ }^{118}$ The bona fide test will be discussed further below in section 6B and 6C.

${ }^{119}$ See Zurich v Cognition, above n 5, at [73].

${ }^{120}$ Ibid.

${ }^{121}$ See above in section 3A and Kalderimis and Skelton, above n 71, at 282.

${ }^{122}$ See above in section 3A.

${ }^{123}$ See above at section $3 \mathrm{E}$.
} 
demand more from the plaintiff before court proceedings will be allowed. ${ }^{124}$ This reluctance to allow proceedings is also evidenced by the Canadian and South African academics and law commission sources which are currently recommending law reform in favour of curtailing the court's ability to allow proceedings. ${ }^{125}$ The decision in Zurich is clearly against the general trend favouring the independence of arbitration.

Admittedly the need for consistency between arbitral regimes internationally is weakened by the facts of the case. Despite one party being from Australia, both parties chose New Zealand as the seat of arbitration and that New Zealand arbitration rules and law would apply to the policy. ${ }^{126}$ It is therefore difficult for either party to claim that the New Zealand courts are not an appropriate forum to hear the dispute. Their arbitration agreement shows that both parties have a strong connection to New Zealand. Such a connection is typically required to defeat challenges to the jurisdiction of New Zealand courts. ${ }^{127}$ Furthermore the Court recognises the value of autonomy and hold that imposing the Court's jurisdiction is consistent with the wishes of the parties as expressed in their agreement. ${ }^{128}$

It may be that the Court does not appreciate the delay that may result from the ease at which summary judgment may be obtained in relation to disputes referred to arbitration. Kalderimis and Skelton document the significant delay which has befallen the parties in Zurich: ${ }^{129}$

In Zurich, the plaintiff's summary judgment application was filed on 9 March 2012, with a procedural hearing held on 27 November 2012. The Court of Appeal's decision was heard in February 2013, with a decision given on 29 May 2013. Leave to appeal is presently being sought before the Supreme Court. And all of this before the defendant's protest to jurisdiction is heard, a substantive summary judgment hearing is held (presently scheduled for September 2013), a decision given - and, if unsuccessful - the parties are then required to commence arbitration.

It seems therefore that seeking summary judgment may not always be "a timely and efficient means of resolution" when the parties have a prior arbitration agreement. ${ }^{130}$ If the policy of the added words is to prevent the parties to be "forced into the expense of full scale arbitration" it may be that seeking summary judgment is not always a reliable alternative. ${ }^{131}$

\footnotetext{
${ }^{124}$ See above at section 3D.

${ }^{125}$ See above at section 3D and 3E.

126 See Zurich $v$ Cognition, above n 5, at [10] and [74].

${ }^{127}$ See Wing Hung Printing Co v Saito Offshore Pty Ltd, above n 84, at [30].

128 See Zurich v Cognition, above n 5, at [74].

${ }^{129}$ See Kalderimis and Skelton, above n 71, at 281.

${ }^{130}$ See Zurich v Cognition, above n 5, at [75].

131 Ibid.
} 
For commercial reasons it may have been in the interests of Zurich to have kept its dispute with Cognition confidential. Cognition's summary judgment application and the subsequent review has now meant that this opportunity is gone. The existence of a dispute between the parties has been reported in the New Zealand Law Reports and has been the subject of argument in open court. ${ }^{132}$

\section{PROPOSED AMENDMENTS TO ARTICLE 8(1)}

It is clear from the foregoing analysis that New Zealand's current approach to summary judgment applications on a matter subject to an arbitration agreement is unsatisfactory. It is necessary therefore to formulate alternative approaches to the question of judicial intervention which are theoretically, comparatively and practically sound. Maybe most importantly a distinction must be made between international and domestic arbitration.

\section{A Deleting the Added Words}

Deleting the added words would be for New Zealand to follow developments in Malaysia, England and Singapore in order to meet its obligations under the New York Convention. ${ }^{133}$ This may encourage international commerce being conducted in New Zealand. The added words represent the defeasibility of arbitration agreements with New Zealand parties and a threat to international parties that they may be answerable to New Zealand courts, something they may not have directly bargained for. ${ }^{134}$ Alternatively international parties may have an unfair advantage over New Zealand residents in subsequent court proceedings because it may be easier for them to prove that New Zealand is not the appropriate forum to hear their dispute as discussed above. ${ }^{135}$

The independence of arbitration is realised by deleting the added words. It respects the autonomy of the parties in choosing that an arbitral tribunal will be the sole determiner of their dispute. ${ }^{136}$ It may be that domestic parties find comfort in being able to resort to the courts if they are not satisfied with their arbitration. Domestic parties do not have the same jurisdictional concerns as international parties and the need for consistency between arbitral regimes is not relevant.

\footnotetext{
${ }^{132}$ Zurich Australian Insurance Ltd v Cognition Education Ltd [2013] 3 NZLR 219 (CA).

${ }^{133}$ See above at section 3 .

${ }^{134}$ See Zurich v Cognition, above n 5, at [26].

${ }^{135}$ See above at section 4B.

${ }^{136}$ See Zurich $v$ Cognition, above n 5, at [26].
} 


\section{B The Subjective Approach}

The subjective approach would refer bona fide albeit unarguable disputes back to arbitration. This approach argued for unsuccessfully in Zurich addresses the potential for defendants to abuse the court's deference to the arbitration agreement. ${ }^{137}$ It recognises that is not appropriate to stay proceedings when a party is simply trying to prolong the resolution of the dispute in a way which exhibits bad faith. At the same time this approach upholds the autonomy of the parties by deferring to the arbitral tribunal's assessment of the merits of a dispute.

While this approach fits well with the general movement towards limiting judicial intervention, there are practical problems with adopting a bona fide test. Without first considering the merits of the dispute, it may be difficult for judges to distinguish between a party who genuinely thinks that there is a dispute and a party who is merely asserting a dispute for the purpose of delaying the resolution of the matter. ${ }^{138}$ Inevitably there are cases where a matter is so indisputable that the only inference is that a party is acting in bad faith if its claims that there is a genuine dispute to be referred to arbitration. ${ }^{139}$ It will be difficult to identify such cases without first establishing that the matter is objectively indisputable. A bona fide test which does not take into account the merits of a dispute is therefore an artificial limitation on the discretion of the courts to stay proceedings and has the potential to be abused by parties seeking to prolong the resolution of the dispute.

The Court of Appeal in Zurich refers to developments under the Model Law to suggest that even without the added words it is likely that a court has the power to engage in a good faith inquiry. ${ }^{140}$ This would make it unnecessary to explicitly spell out a bona fide test. The Court was likely referring to Article $2 \mathrm{~A}(1)$ of the Model Law which requires an interpretation of the Law consistent with the observance of good faith. ${ }^{141}$

\section{The Heightened Objective Approach}

In Canada the courts will not stay proceedings on a matter subject to an arbitration agreement unless the claimant's claim has a "high prospect of success." ${ }^{142}$ This approach is based on the jurisdictional theory because it necessarily allows the court to assess the merits of a dispute referred to arbitration. It seems to place a higher premium on the parties' decision to refer their dispute to

\footnotetext{
${ }^{137}$ See Zurich v Cognition, above n 5, at [7].

${ }^{138}$ See Cognition v Zurich, above n 1, at [49].

${ }^{139}$ Merrill Lynch Pierce, Fenner \& Smith Inc v Prem Ramchand Harjani [2009] SGHC 133 at [21].

${ }^{140}$ See Zurich v Cognition, above n 5, at [68].

${ }^{141}$ UNCITRAL Model Law on International Commercial Arbitration (United Nations Publications, Vienna, 2008) at art $2 \mathrm{~A}(1)$.

${ }^{142}$ See above at section 3D.
} 
arbitration than the "arguable defence" test. This is because it requires a higher standard of proof before it allows a party to avoid its arbitration agreement.

Adopting the Canadian approach would mean that the courts would be more likely to stay court proceedings and refer the parties to arbitration, a result which would give some confidence to international parties making arbitration agreements with New Zealand parties. However this test may undermine a main purpose for why parties apply to the courts to avoid an arbitration agreement, namely the hope of a timely resolution of the matter. A higher standard of proof may in some cases require additional evidence to be produced and this will likely prolong the dispute resolution.

\section{Optional Application of the Added Words}

It has been suggested that the added words should be moved to the Second Schedule of New Zealand's current Arbitration Act. ${ }^{143}$ The added words if in Schedule 2 would only apply to international arbitration if the parties so agreed. ${ }^{144}$ For domestic arbitrations, the added words would apply automatically unless the parties agree otherwise. ${ }^{145}$

This approach would align New Zealand with the developing autonomy theory of international arbitration. The autonomy theory recognises that the national laws of the seat of arbitration should not be mandatory on parties to an arbitration agreement. ${ }^{146}$ An interesting question is whether this approach conflicts with New Zealand's obligations under the New York Convention. As outlined above, the treaty requires that states enforce international arbitration agreements except in the specified circumstances which do not include the added words. ${ }^{147}$ However the optional application of the added words is not inconsistent with the treaty's purpose of preventing contracting states from impose onerous requirements before recognising arbitration agreements. ${ }^{148}$

If an international party consents to the application of the added words it would be difficult to them to turn around and say that the New Zealand courts are a forum non conveniens. This is because of the acceptance of the jurisdiction of the New Zealand courts implicit in the advertent inclusion of the added words in their arbitration agreement. This protects New Zealand residents against jurisdictional challenges and provides clarity to international parties uncertain about the defeasibility of arbitration agreements with New Zealand parties. The opt-out presumption in Schedule 2

\footnotetext{
${ }^{143}$ See Kalderimis and Skelton, above n 71, at 286.

144 Arbitration Act (New Zealand) 1996, s 6(2)(a).

${ }^{145}$ Ibid at s 6(2)(b).

${ }^{146}$ See above at section $2 \mathrm{~A}$.

${ }^{147}$ See above at section $3 \mathrm{~A}$.

148 Ibid.
} 
represents an understanding that the independence of international parties is likely to be preferred while respecting the autonomy of the parties to choose otherwise.

The opt-out requirement for domestic arbitration agreement recognises that jurisdictional issues and nationality differences are not as relevant to domestic parties. This is to be preferred to having mandatory rules for domestic arbitration agreements as is the case in England and Singapore. ${ }^{149}$ Such an approach would disadvantages parties to a domestic arbitration whose particular concerns such as confidentiality are best met by greater independence from the judicial system.

\section{CONCLUSION}

Zurich $v$ Cognition raised questions over the extent to which the courts should allow a party avoid their agreement to arbitrate under art $8(1)$. There are three reasons why this is an unfortunate development in New Zealand arbitration law.

Firstly extending judicial control over arbitration cannot justifiably extend to international arbitration. The autonomy theory of arbitration demonstrates that the independence of international arbitration is necessary for parties to reconcile the differences between their nationalities.

Secondly the independence of international arbitration is recognised internationally. If New Zealand allows their courts a greater level of discretion over staying proceedings brought in relation to international arbitration then it will invite jurisdictional challenges and the perception that arbitration agreements with New Zealand parties are easily defeasible.

Thirdly encouraging parties to seek summary judgment instead of persisting with their arbitration will mean that the party seeking to stay proceedings will be disadvantaged. The benefits of arbitration such as efficiency, confidentiality and suitability are challenged and potentially defeated when one party decides to bring court proceedings.

It is therefore necessary to formulate an alternative approach to staying applications for summary judgment on a matter subject to an arbitration agreement. The independence of arbitration is best served by moving the added words in art 8(1) to schedule 2 of the Arbitration Act where they would apply to international arbitration optionally. This recognises that allowing the court to assess the merits of a dispute referred to international arbitration is unusual. It legitimises judicial intervention by requiring the consent of international parties first. The opt-out basis for domestic arbitration agreements recognises that jurisdictional issues and nationality differences are not as relevant to domestic, but it nevertheless respects the autonomy of parties to agree otherwise.

${ }^{149}$ See above at section at $3 E$. 


\section{BIBLIOGRAPHY}

\section{A Texts}

N Blackaby and others, Redfurn and Hunter on International Arbitration (5th ed, OUP, Oxford, 2009).

Gary B. Born, International Arbitration: Cases and Materials (Wolters Kluwer, New York, 2011).

Gary B. Born, International Commercial Arbitration ( $3^{\text {rd }}$ ed, Klumer Law International, Alphen Aan Den Rijn, 2009).

Julian DM Lew and others, Comparative International Commercial Arbitration (Kluwer Law International, The Hague, 2003).

Lord Michael Mustill \& Stewart Boyd, The Law and Practice of Commercial Arbitration in England (2nd ed, Butterworths, London, 1989).

Adam Samuel, Jurisdictional Problems in International Commercial Arbitration - A Study of Belgian, Dutch, English, French, Swedish, Swiss, US and West German Law (Schulthess, Zurich, 1989).

David A R Williams and Amokura Kawharu, Williams and Kawharu on Arbitration (LexisNexis, Wellington, 2011).

Desmond Williams, "South Africa" in J. William Rowley QC (ed) Arbitration World (3" ed, The European Lawyer Reference, London).

\section{B Articles}

Thayananthan Baskaran "Recent Amendments to the Malaysian Arbitration Act" (2012) 28 LCIA 533.

David Butler "South Africa arbitration legislation - the need for reform" (1994) 17 CILSA 118. 
Kenneth S. Carlston "Theory of the Arbitration Process" (1952) 17 LCP 631.

Daniel Kalderimis and Nikolas Bruce-Smith "To stay or not to stay" (2013) NZLJ 232.

Daniel Kalderimis and Andrew Skelton "Summary Judgment and Arbitration: The contest between pragmatism and principle"17 NZACL 263.

Ole Lando "The Lex Mercatoria in International Commercial Arbitration" (1985) 34ICLQ 747.

Francis A. Mann “Lex Facit Arbitrum” (1983) 2 ARB. INT'1 245.

Hong-lin $\mathrm{Yu}$ "A Theoretical Overview of the Foundations of International Commercial Arbitration" (2008) 1CAA 255.

\section{Tables of Statutes: New Zealand}

Arbitration Act 1908.

Judicature Act 1908 .

Arbitration Clauses (Protocol) and the Arbitration (Foreign Awards) Act 1933.

Arbitration (Foreign Agreements and Awards) Act 1982.

Arbitration Act 1996.

D Tables of Statutes: United Kingdom

Arbitration Act 1950.

Arbitration Act 1975.

Arbitration Act 1996.

\section{E Table of Statutes: Canada}

Arbitration Act, RSA 2000, c A-43.

\section{F Table of Statutes: Singapore}

International Arbitration Act 1994.

Arbitration Act 2001. 


\section{G Table of Statutes: Malaysia}

Arbitration Act 1952.

Arbitration Act 2005.

\section{H Table of Statutes: South Africa}

Arbitration Act 1965.

\section{Model Law}

UNCITRAL Model Law on International Commercial Arbitration (United Nations Publications, Vienna, 2008).

\section{J International Treaties}

Convention on the Recognition and Enforcement of Foreign Arbitral Awards, (signed 10 June 1958, entered into force 7 June 1959), 330 U.N.T.S. 38.

\section{K Table of Cases: New Zealand}

Baltimar Aps Ltd v Nalder \& Biddle Ltd [1994] 3 NZLR 129 (CA).

Cognition Education Ltd v Zurich Australian Ltd t/a Zurich New Zealand [2012] NZHC 3527.

Zurich Australian Insurance Ltd t/a Zurich New Zealand v Cognition Education Ltd [2013] NZCA 180.

Danone Asia Pacific Holdings Pte Ltd v Fonterra Co-Operative Group Ltd [2014] NZHC 393.

Jowada Holdings Ltd v Cullen Investments Ltd CA248/01, 5 June 2003.

Ngai Tahu Justice Holdings Ltd v Attorney-General [2013] NZHC 801.

Pemberton v Chappell [1987] 1 NZLR 1 (CA).

Royal Oak Mall Ltd v Savory Holdings Ltd CA106/89, 2 November 1989.

Wing Hung Printing Co v Saito Offshore Pty Ltd [2011] 1 NZLR 754 (CA).

\section{Table of Cases: United Kingdom}

Hayter v Nelson \& Home Insurance Co [1990] 2 Lloyd's Rep 265 (QB).

\section{Table of Cases: United States of America}

Reily v. Russel (1864) 34 Mo 524. 


\section{$N$ Table of Cases: Canada}

Balancing Pool v TransAlta Utilities Corporation, 2008 ABQB 631.

Smith Estate v. National Money Mart Co., [2008] O.J. No. 2248.

\section{O Table of Cases: Malaysia}

KNM Process Systems Sdn Bhd v Mission Biofuels Sdn Bhd [2012] MLJU 1218.

\section{$Q$ Table of Cases: Singapore}

Merrill Lynch Pierce, Fenner \& Smith Inc v Prem Ramchand Harjani [2009] SGHC 133.

\section{R Law Reform: New Zealand}

Law Commission Arbitration (NZLC R20, 1991).

Law Commission Improving the Arbitration Act 1996 (NZLC R83, 2003).

K. Saville-Smith and R. Fraser Alternative Dispute Resolution: General Civil Cases (Ministry of Justice, June 2004).

\section{S Law Reform: United Kingdom}

"A New Arbitration Act for the United Kingdom? The Response of the Departmental Advisory Committee to the UNCITRAL Model Law" (1990) 6 Arbitration International 3.

Departmental Advisory Committee on Arbitration Law Report on Arbitration Bill (February 1996).

\section{T Law Reform: Canada}

The Alberta Institute of Law Research and Reform "Proposals for a New Alberta Arbitration Act" (October 1988).

Alberta Law Reform Institute Arbitration Act: Stay and Appeal Issues 2013.

\section{U Law reform: South Africa}

South African Law Commission Issue Paper (Project 94) Arbitration: An International Arbitration Act for South Africa (1998). 


\section{Webpages}

Building Disputes Tribunal <www.buildingdisputestribunal.co.nz>

New Zealand Dispute Resolution Centre <www.nzdrc.co.nz>

UNCITRAL "Status - Convention on the Recognition and Enforcement of Foreign Arbitral Awards (New York, 1958)" UNCITRAL.

<http://www.uncitral.org/uncitral/en/uncitral_texts/arbitration/NYConvention_status.html>

Word count: The length of this research paper is 7938 words, excluding abstracts, nonsubstantive footnotes, appendices and bibliographies. Substantive footnotes amount to 37 words. 